\title{
THE
}

\section{A Comparison of Plants and Animals in Their Responses to Risk of Consumption}

Richard Karban

John L. Orrock

Evan L. Preisser

University of Rhode Island, preisser@uri.edu

Andrew Sih

Follow this and additional works at: https://digitalcommons.uri.edu/bio_facpubs

Terms of Use

All rights reserved under copyright.

\section{Citation/Publisher Attribution}

Karban, R., Orrock, J. L., Preisser, E. L., \& Sih, A. (2016). A Comparison of Plants and Animals in Their Responses to Risk of Consumption. Current Opinion in Plant Biology, 32, 1-8.

Available at: http://dx.doi.org/10.1016/j.pbi.2016.05.002

This Article is brought to you for free and open access by the Biological Sciences at DigitalCommons@URI. It has been accepted for inclusion in Biological Sciences Faculty Publications by an authorized administrator of DigitalCommons@URI. For more information, please contact digitalcommons-group@uri.edu. 


\section{A comparison of plants and animals in their responses to risk of consumption Richard Karban ${ }^{1}$, John L Orrock ${ }^{2}$, Evan L Preisser ${ }^{3}$ and Andrew $\operatorname{Sin}^{4}$}

\begin{abstract}
Both plants and animals reduce their risk of being eaten by detecting and responding to herbivore and predator cues. Plants tend to be less mobile and rely on more local information perceived with widely dispersed and redundant tissues. As such, plants can more easily multi-task. Plants are more tolerant of damage and use damage to their own tissues as reliable cues of risk; plants have a higher threshold before responding to the threat of herbivory. Plants also use diverse cues that include fragments of plant tissue and molecular patterns from herbivores, herbivore feeding, or microbial associates of herbivores. Instead of fleeing from attackers, plants reallocate valuable resources to organs at less risk. They minimize unnecessary defenses against unrealized risks and costs of failing to defend against actual risk. Plants can remember and learn, although these abilities are poorly understood.
\end{abstract}

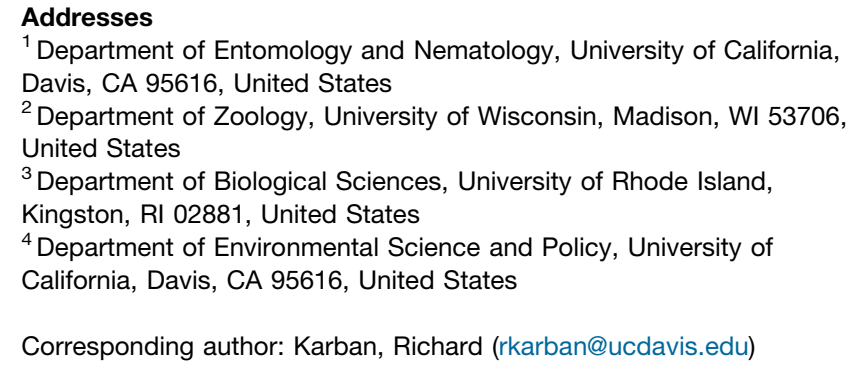

${ }^{1}$ Department of Entomology and Nematology, University of California, Davis, CA 95616, United States

${ }^{2}$ Department of Zoology, University of Wisconsin, Madison, WI 53706, United States

${ }^{3}$ Department of Biological Sciences, University of Rhode Island, Kingston, RI 02881, United States

${ }^{4}$ Department of Environmental Science and Policy, University of California, Davis, CA 95616, United States

Corresponding author: Karban, Richard (rkarban@ucdavis.edu)

Current Opinion in Plant Biology 2016, 32:1-8

This review comes from a themed issue on Biotic interactions

Edited by Consuelo De Moraes and Mark Mescher

http://dx.doi.org/10.1016/j.pbi.2016.05.002

1369-5266/C 2016 Elsevier Ltd. All rights reserved.

\section{Introduction}

The essential challenges faced by plants and animals are quite similar - individuals must procure enough resources to grow, avoid becoming food for predators, parasites, and pathogens, and successfully transmit their genes to subsequent generations. They increase their chances of success by perceiving cues from their abiotic and biotic environments and altering their allocation to growth, defense, and reproduction. Behavior can be defined as this conditional, often reversible, cue-induced change in phenotype $\left[1^{\bullet \bullet}\right]$. Despite these fundamental similarities between plants and animals, many scientists have considered animals as uniquely capable of sensing and behaviorally responding to their environments.

Plants, as well as animals, perceive cues that are reliable predictors of current and future conditions $\left[1^{\bullet \bullet}\right]$. Risk of attack by herbivores and predators is a particularly important environmental condition. Both plants and animals modify their allocation to defense when information can reliably predict risk of attack $\left[2,3^{\bullet \bullet}\right]$. In this review, we identify the fundamental differences between animals and plants and argue that these differences causally shape how the two groups perceive, process, and respond to information regarding risk of attack (summarized in Figure 1). We compare plants to mobile animals with central nervous systems; sessile, clonal animals are more similar to plants in many regards.

\section{Differences between plants and animals and how they shape behavior \\ Movement}

Most plants require $\mathrm{CO}_{2}$, water, and sunlight, rapidly renewable resources that can be obtained while sessile; most animals are forced to be much more mobile to obtain resources that renew slowly. As a result, many mobile animals move throughout relatively large areas (e.g., home ranges) and reduce risk by changing location. In addition, this difference in movement constrains the spatial extent of information that an individual can access. Plants are likely to receive most of their information from relatively nearby [4]. Movement differences between plants and animals also shape the mechanisms of perception. For example, plants benefit most from cues that operate over short spatial scales (e.g., volatile chemicals), whereas mobile animals also use cue modalities that provide information over greater distances (e.g., vision). Fundamental differences in movement also constrain the behavioral responses to risk for plants and animals (see below). A relatively small detection area means that plants have less time to respond before encountering an herbivore. Small detection area plus a slower response time make it harder for plants to mount effective induced defenses before being partially consumed.

\section{Centralized versus decentralized perception and response}

Plant bodies are not as specialized as animal bodies [5]. Animals are composed of specialized organs of which 


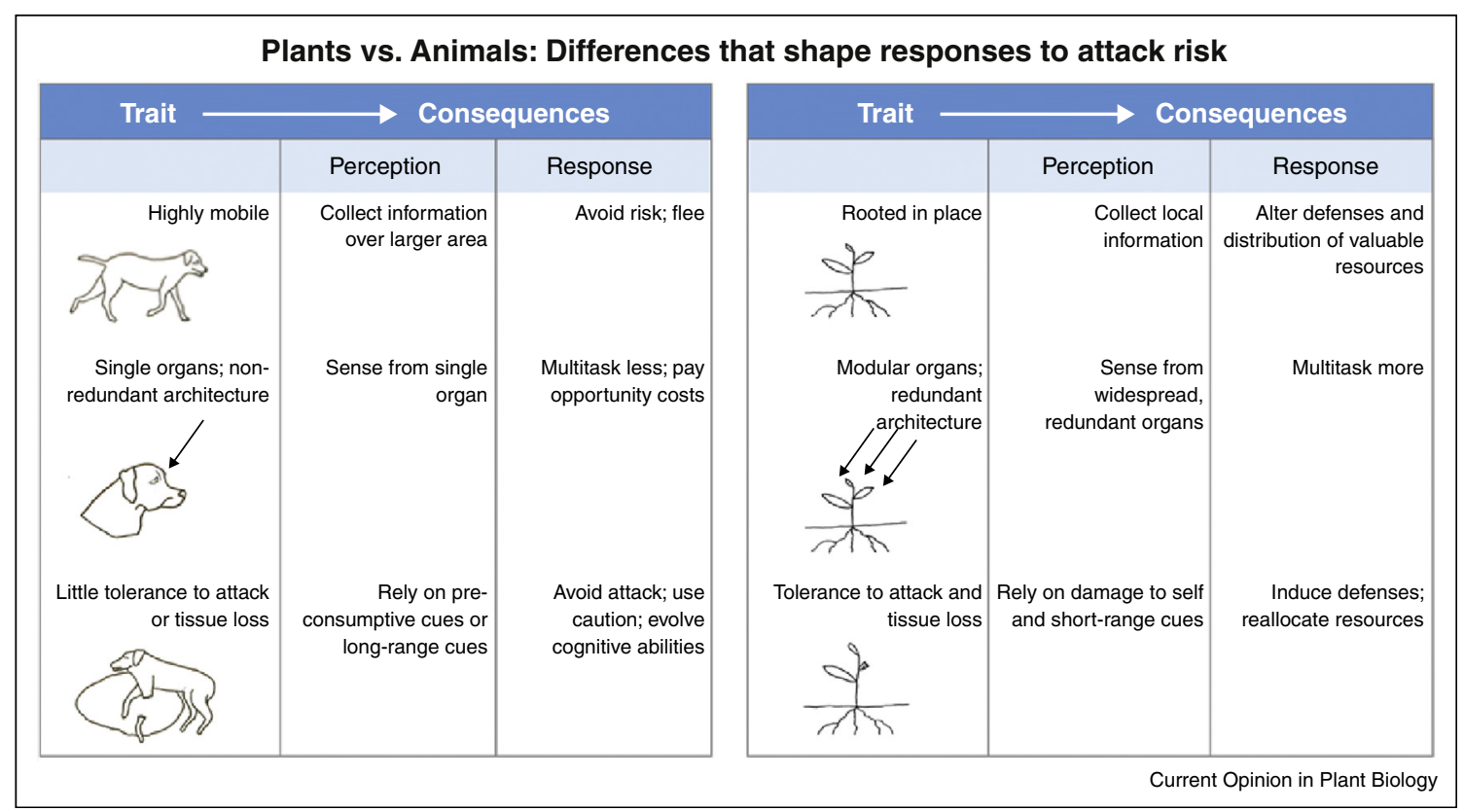

Fundamental differences between plants and animals shape the ways they perceive their environments and respond (see also [75,76]). Plants, unlike animals, are less mobile (top), are constructed of repeated modular units (middle), and are more tolerant of attack and loss of some tissue (bottom). Low mobility leads plants to collect more local information and to respond by reallocating resources instead of moving. Modular architecture leads plants to have decentralized tissues that perceive cues and to be better able to multi-task. Tolerance to tissue loss allows plants to collect personal post-consumptive cues of risk and to rely on induced reallocation following attack.

there are one or relatively few copies (e.g., one brain, two eyes, one mouth). Plants are composed of multiple copies of redundant tissues and organs. Rather than two eyes located in the head, each leaf of a plant can be exquisitely sensitive to subtle variations in light quality and quantity. Plant meristems can give rise to almost any tissue at almost any time during development, providing plants with far greater morphological plasticity than most animals. This redundancy, decentralization, and plasticity allow plants to perceive risk and respond while carrying out other important tasks (e.g., foraging); animals, in contrast, often pay relatively large costs in terms of missed opportunities because time spent assessing and responding to risk cannot be spent on other activities.

\section{Tolerance to attack}

Plants are much more tolerant of herbivory than animals are of predation $\left[3^{\bullet \bullet}, 6\right]$. Since plants are made up of repeated semi-autonomous units, they can afford to lose some of these tissues without suffering severe reductions in fitness. Undifferentiated plant meristems can replace damaged or missing tissue. In contrast, animals are much less tolerant of attack since removal of even small amounts of tissue is often irreplaceable and leads to loss of fitness or death $\left[3^{\bullet \bullet}\right]$. These differences affect the mechanisms of perception because plants can use their own tissues to gain accurate information. Animals, in contrast, may make more sophisticated use of information obtained early in the attack sequence and be under stronger selection for cognitive abilities allowing recognition and synthesis of information about risk before actual attack.

\section{Cues about risk of attack}

Both animals and plants perceive light, chemical, mechanical, sound, and electrical cues that provide information about attack risk $\left[1^{\bullet \bullet}, 7^{\bullet}\right]$. These different sensory modalities provide information of varying quality that shapes the usefulness and reliability of cues for an individual animal or plant.

The modalities of sensing systems and cues are welldescribed for animals and we will build upon summary tables from this literature $\left[7^{\bullet}, 8\right]$ to include plant sensing for comparison (Table 1). Several observations about these comparisons are worth noting. First, the relevant properties of cues (their range, how long they persist) are intrinsic to the cue and subject to environmental degradation; these properties are independent of the organisms that may perceive them. As a result, both plants and animals are sensitive to conditions that degrade cue reliability. For instance, plants in chronically windy environments may adjust their sensitivities and rely on constitutive defenses [9]. Second, plants have sensing systems that are functionally analogous to those of animals; these systems allow plants to perceive the same broad categories of cues $\left[1^{\bullet \bullet}\right]$. Third, animal receptors are often 
Table 1

\begin{tabular}{|c|c|c|c|c|c|c|c|c|}
\hline \multirow[t]{2}{*}{ Modality } & \multirow[t]{2}{*}{ Range } & \multirow[t]{2}{*}{ Persistence } & \multicolumn{3}{|c|}{ Animal } & \multicolumn{3}{|c|}{ Plant } \\
\hline & & & Receptor & Salient feature & Example & Receptor & Salient feature & Example \\
\hline \multirow[t]{2}{*}{ Light } & $\begin{array}{l}\text { Short - } \\
\text { long }\end{array}$ & $\begin{array}{l}\text { Short - } \\
\text { long }\end{array}$ & Camera eye & Size, color & $\begin{array}{l}\text { Primates spot } \\
\text { snakes [65] }\end{array}$ & Phytochrome & Red: far red ratio & $\begin{array}{l}\text { Shade } \\
\text { avoidance [66] }\end{array}$ \\
\hline & $\begin{array}{l}\text { Short - } \\
\text { long }\end{array}$ & $\begin{array}{l}\text { Short - } \\
\text { long }\end{array}$ & $\begin{array}{l}\text { Compound } \\
\text { eye }\end{array}$ & $\begin{array}{l}\text { Speed, } \\
\text { direction } \\
\text { of movement }\end{array}$ & $\begin{array}{l}\text { Insects track } \\
\text { movement [67] }\end{array}$ & $\begin{array}{l}\text { Phototropins, } \\
\text { cryptochromes }\end{array}$ & Blue light & $\begin{array}{l}\text { Orientation of } \\
\text { seedlings [68] }\end{array}$ \\
\hline \multirow[t]{2}{*}{ Chemical } & Short & Short & Various & $\begin{array}{l}\text { Conserved } \\
\text { molecular } \\
\text { patterns }\end{array}$ & $\begin{array}{l}\text { Immunity in } \\
\text { mammals [69] }\end{array}$ & MAP kinases & $\begin{array}{l}\text { Herbivore-specific } \\
\text { chemicals }\end{array}$ & $\begin{array}{l}\text { Increased } \\
\text { resistance [70] }\end{array}$ \\
\hline & Medium & Medium & $\begin{array}{l}\text { Nerve cells } \\
\text { in specialized } \\
\text { organ }\end{array}$ & Concentration & $\begin{array}{l}\text { Tadpole } \\
\text { neurons } \\
\text { perceive } \\
\text { predator cue } \\
{\left[11^{\bullet \bullet}\right]}\end{array}$ & Unknown & $\begin{array}{l}\text { Volatiles emitted } \\
\text { by neighbors }\end{array}$ & $\begin{array}{l}\text { Transcription } \\
\text { changes } \\
\text { increase } \\
\text { resistance }\left[27^{\circ}\right]\end{array}$ \\
\hline Sound & $\begin{array}{l}\text { Medium - } \\
\text { long }\end{array}$ & Short & $\begin{array}{l}\text { Pressure } \\
\text { detector }\end{array}$ & $\begin{array}{l}\text { Frequency, } \\
\text { amplitude, } \\
\text { duration }\end{array}$ & $\begin{array}{l}\text { Moths hear } \\
\text { predators [71] }\end{array}$ & Unknown & $\begin{array}{l}\text { Specific insect } \\
\text { properties }\end{array}$ & $\begin{array}{l}\text { Increased } \\
\text { resistance [72] }\end{array}$ \\
\hline Mechanical & Short & Short & Nerve cell & $\begin{array}{l}\text { Size and } \\
\text { frequency } \\
\text { of disturbance }\end{array}$ & $\begin{array}{l}\text { Crickets sense } \\
\text { speed of } \\
\text { predator [73] }\end{array}$ & $\begin{array}{l}\text { Glandular } \\
\text { trichomes }\end{array}$ & $\begin{array}{l}\text { Rupture of } \\
\text { trichome }\end{array}$ & $\begin{array}{l}\text { Plant responds } \\
\text { to insect } \\
\text { footsteps [74] }\end{array}$ \\
\hline
\end{tabular}

centralized in a small number of specialized organs while plant receptors are found on many cells of a particular tissue type distributed throughout the individual. Fourth, while plant biologists have recently documented that plants respond to many chemical and acoustic cues, little is known about the receptors and mechanisms of perception.

\section{Cues vary in reliability and cost to obtain}

Models of plastic behaviors highlight the importance of cue reliability [10]. This result makes intuitive sense responding to cues only increases fitness if organisms respond appropriately to accurate information. Plants gather information from close range while cues that animals collect come from a greater spatial range.

Animal biologists have categorized cues in ways that emphasize their reliability and information content; these will likely be useful for plant biologists. For example, cues may be categorized as pre-consumptive or postconsumptive $\left[11^{\bullet \bullet}\right]$. Pre-consumptive cues include chemicals that predators constitutively release (early warning signals [12]) while post-consumptive cues include chemicals associated with cell fragments from other animals that have been preyed upon or from predator feces (feeding signals [12]). Post-consumptive cues used by animals originate from successful attacks on other individuals but can originate from the same individual plant. Cues from predators tend to shape response type while cues from prey determine response intensity $\left[11^{\circ \bullet}\right]$. Cues can also be characterized by whether they are produced directly by the attacker (e.g., predator urine or herbivore mating pheromones), or from a successful attack (cell wall fragments or molecules). Direct cues from predators or predation events contrast with indirect cues, which indicate a risky environment $[13,14]$.

Obtaining reliable cues often entails considerable risk. Plants and animals may pay different costs for reliable information and these costs may structure the primary sources of information that each relies on. For example, because plants can tolerate partial consumption, actual consumption by herbivores provides a highly reliable indicator of attack risk. Animals typically cannot afford to gather information in this way because any successful predator attack can have catastrophic consequences. Instead, animals pay costs in terms of time, energy, and missed opportunities in order to gather information about risk (e.g., remaining vigilant while foraging). Indeed, when costs of gathering information about risk are very high, animals spend much of their time hiding even when predators are rare [10]. The inability of animals to tolerate successful attack may also select for sophisticated use of risk information obtained from others (social information) with associated costs of increased competition, deception, and manipulation.

\section{Plant cues provide information about herbivores}

The best-studied cues of herbivory are actual damage to the responding plant (post-consumptive, direct plant cues). For example, homogenates of bean plants applied to unattacked plants increased several markers of resistance against insects and pathogens [15]. In these experiments, plants responded most strongly to cues from their own tissues or those of closely related individuals. Cell wall fragments, extracellular DNA, and extracellular ATP are generalized cues of physical damage that elicit responses in both plants and animals $\left[16^{\circ}\right]$. 
Plants gain information about risk from varied sources. They recognize specific molecular patterns in herbivoredamaged plant tissues (post-consumptive, direct plant cues), in oral secretions of chewing herbivores (postconsumptive, direct herbivore cues), and in microbes that herbivores introduce as they feed (post-consumptive, indirect herbivore cues) $\left[17,18^{\circ}\right]$. The herbivore chemicals that elicit recognition by plants are essential components that attackers cannot easily change or do without, such as those used in nitrogen metabolism [19]. Many plants also recognize fluids associated with insect eggs (pre-consumptive, direct herbivore cues) $\left[20,21^{\circ}\right]$ and even herbivore mating pheromones [22]. Since plants respond more slowly than animals, early recognition may allow plants to mount defenses before actually losing tissue, since eggs and mating pheromone should be reliable cues that feeding herbivores are in a plant's immediate future.

Like predators, herbivores are under strong selection to remain chemically camouflaged and avoid detection by their host plants. Some herbivores appear to avoid detection by reducing production of cues recognized by their hosts $\left[23^{\bullet \bullet}\right]$. Feeding or ovipositing herbivores also fool plants by introducing microbes or other cues that are normally associated with microbes; this misperception causes plants to defend against microbial attack, reducing their abilities to resist insects $\left[24,25^{\circ}\right]$.

Plants are less able to circulate cues through their vascular and nervous systems than are animals [26]. Instead, they rely on volatile cues that are emitted at the site of attack to coordinate systemic defenses against further herbivory $\left[27^{\circ}\right]$. Volatile cues that likely evolved to coordinate systemic defenses of individuals can also be sensed by neighboring plants [28]. Sagebrush plants were found to respond more strongly to volatiles from genetically identical (self) tissues than genetically different tissues, and to cues from relatives more than strangers [29,30]. This progression in responsiveness reflects a progression in reliability of cues.

There is one provocative report of pea plants sensing stress cues of neighbors that they contact underground; these plants responded and passed on information to other neighbors that were farther away from the original stressed individual [31]. The reliability of this secondhand information is presumably reduced and further work is required to evaluate the generality of this phenomenon.

\section{How do animals and plants respond to risk?}

The fundamental differences in movement, modularity, and tolerance shape the behaviors that animals and plants exhibit in response to risk (Figure 1) $\left[3^{\bullet \bullet}\right]$. For example, rooted plants cannot flee an attacker so their behavioral responses to risk necessarily involve changing defensive morphology or chemistry or translocating valuable molecules to unattacked tissues [32]. These plant responses are often slower than the speed of movement of many herbivores. For mobile animals, movement is often the most important line of defense as they avoid places with high risk and flee from predators that they encounter [33]. Foraging decisions are affected by the internal state of the animal [34]; hungry animals are willing to take greater risks to feed.

Since plants are less mobile, they forage on a smaller spatial scale by selectively allocating resources to meristems that will maximize returns. Sun-adapted plants forage by growing into light patches and shedding shaded shoots $[35,36]$. Plants forage for nutrients by proliferating roots in richer soil patches and leaving poorer ones $\left[37,38^{\circ}\right]$. These behaviors place more absorptive surface area in locations with more resources. Foraging decisions by plants follow predictions of state-dependent models developed for animals [34]. For example, shaded plants allocate resources preferentially towards growth and away from defense $[39,40]$ and light-starved plants are willing to tolerate greater risk of herbivore attack [41].

Animal biologists note that different types of cues (preconsumptive, post-consumptive, direct, indirect) vary in the responses they elicit. Animals often respond strongly to direct cues (e.g., predator urine) when indirect cues are absent. Studies that compare responses to direct and indirect cues often find the greatest reduction in foraging in risky habitats (an indirect cue) [14]. Indirect cues about habitat presumably provide more reliable information about overall risk from multiple different predators. For example, a mouse foraging on a moonlit night perceives that it is at risk of attack by numerous predators. The urine of one particular predator may provide little additional information about true risk since light levels determine risk from multiple predator species [13]. Plants may also respond to indirect cues of risk. Individuals [42] or organs in risky environments (e.g., branches at a height where browsing mammals can reach them [43]) are more responsive to cues of attack and better defended. Animal behaviorists have categorized predators based on their mobility and found that prey are generally more responsive to cues from less active (ambush) predators [44]. Ambush predators are dangerous but provide less reliable cues than active predators. Plants may also distinguish between stationary herbivores (e.g., aphids, caterpillars) and highly mobile ones (e.g., grasshoppers, deer) but for a slightly different reason; less mobile herbivores often pose greater risks to individual plants.

Although this review compares plants to mobile vertebrate animals, clonal marine invertebrates are the exception that proves the rule [45]. Like plants, these clonal organisms are sessile and composed of redundant tissues and organs. They perceive primarily local cues and rely on morphological plasticity to match risk. They are relatively tolerant of partial consumption and use attacks to self as 
reliable cues. Induced responses are often localized and they are capable or considerable multitasking. Although they are animals, the traits they share with plants has independently led to many similar responses to risk.

\section{Constraints on responses to risk Error management strategies}

Because errors in defense may be costly, but inevitable, selection is expected to favor responses that are biased towards making the least costly errors $\left[3^{\bullet \bullet}\right]$. Since animals often suffer fitness losses from any successful attack, animals should respond strongly to cues that indicate relatively small increases in risk (caution) [34,44]; animals should err towards accepting false alarms in order to avoid the error of failing to defend against a true attack (i.e., better safe than sorry). In contrast, adult plants are expected to err towards accepting an undefended attack because the cost of maintaining unnecessary defenses exceeds the cost of losing a small amount of tissue to an initial herbivore attack $\left[46^{\circ}\right]$. Since adult plants often pay little cost for an undefended attack, factors that increase costs of unnecessary defenses (e.g., highly competitive environments, interference with pollinators) are expected to increase the amount of information about risk required for plants to invest in defense.

In situations where the costs of an undefended attack are high, both error management theory $\left[3^{\circ \bullet}\right]$ and the asset protection principle [47] predict that organisms will invest heavily in constitutive defenses, regardless of available risk information. Organisms are also expected to exhibit constitutive defenses when induced defenses take too long to deploy relative to the timing of attack [10]. Plant induced responses will take longer than animals fleeing.

Empirical data support the notion that costs of undefended attack and unnecessary defense provide insights into how plants respond to risk information. For example, seedlings are much less tolerant of partial consumption [48], and are predicted to err on the side of more defense, similar to animals. Indeed, a meta-analysis found that chemical defenses for woody plants increased during the seedling stage and decreased at later stages [49]. Similarly plants invest heavily in constitutive defense in tissues of high reproductive value (e.g., seeds) but have inducible defenses in leaves and roots, presumably reflecting the high cost of leaving valuable tissues undefended [50].

\section{Cognitive limitations}

The ability to acquire, process, store, and respond to information regarding risk can affect fitness of any organism [51,52]. While it remains controversial whether nonhuman animals, let alone plants, are capable of complex cognition, recent evidence indicates that plants exhibit many of the hallmarks of cognitive traits such as perception (discussed above), learning, and memory. Self-reference in animals, relative to other organisms and spatial features, is considered essential for avoiding predation [53]. Plants also learn their spatial position relative to obstacles and potential risks $\left[54,55^{\circ}\right]$. Plants 'remember' past events and these experiences influence their responses to attack. For example, plants that have been primed by cues of herbivory respond more rapidly and more strongly to actual attack [56,57]. Despite recent realizations that plants are more capable than previously thought, their lack of cognitive abilities certainly constrain plant responses. The ability of plants to process information and to produce effective strategies while balancing conflicting needs is not well understood. An interesting speculation is that the greater cognitive abilities of animals evolved, in part, in response to selection to interpret the wealth of information acquired during movement coupled with an intolerance of attack.

\section{Morphological and evolutionary limitations}

It is axiomatic in animal behavior that no individual can be in more than one place, and that engaging in multiple simultaneous activities entails a compromise (e.g., animals that remain vigilant while foraging do not optimize either task). Although animals multitask to some extent, these constraints apply less to plants. Plants simultaneously acquire different resources, mate, and also defend. While they certainly encounter tradeoffs among these various activities $[58,59]$, their redundant construction allows them to accomplish more tasks simultaneously than animals.

Adaptation is limited by existing variation - natural selection cannot act on traits that have never arisen. The repertoire of plant perception and response to risk has similarly been limited by evolutionary variation, although several key 'animal-associated' traits have also appeared in the plant lineage. For example, while plants do not generally move to escape herbivores, more limited leaf movements or fluttering may provide defense against herbivores $[41,60,61]$.

Similarly, rooted plants cannot collect information from as large an area as mobile animals. However, many plants possess networks of mycorrhizal associates that extend the scale of information acquisition far beyond the extent of that individual's roots, at least tens of meters and probably much farther $\left[62^{\circ}\right]$. Information transferred by mycorrhizal networks can allow plants to induce defenses before attack $\left[63,64^{\circ}\right]$. We predict that information acquired from mycorrhizal associates comes from a greater distance but is less reliable than information collected by an individual itself; therefore, plants may respond less to these cues.

\section{Future directions}

Since animal biologists have been thinking about perception and response to risk for decades, they have made 
Box 1 Research priorities for plant biologists suggested by a comparison with the animal literature

Perception - Animal biologists have a much better developed understanding of the receptors involved in perceiving diverse environmental cues (e.g., $\left.\left[7^{\circ}\right]\right)$. This knowledge facilitated progress in understanding perceptual mechanisms and in answering 'ultimate' questions about where and why different responses are observed. By comparison, plant biologists know very little about the receptors and mechanisms of perception (Table 1) and gaining this information represents an area of critical need.

Response - Animal biologists have made significant progress in understanding behavior by employing game and optimality theory and related approaches. While a few plant biologists have recognized the potential for applying this body of theory to plant behavior (e.g., $\left.\left[3^{\circ *}, 38^{\circ}\right]\right)$, theoretical considerations of plant responses represent low-hanging fruit that should yield important insights.

Individual animals have also been found to exhibit consistent 'personalities' in multiple contexts (e.g., individuals that are bold around predators are also aggressive around competitors) [77]. Recognition of correlated behaviors among individuals has led to new insights into long-standing ecological issues. Plant behaviors may also be correlated across multiple situations with interesting consequences.

Cognition - While some may object to the use of this term, it seems undeniable that plants have the ability to store, process, and evaluate information from a variety of sources. Plant biologists have begun to explore how plants integrate different (sometimes contradictory) inputs. Since cognition may have evolved to allow animals to prioritize the diverse inputs that they receive, it will be interesting to test whether plants that receive more kinds of inputs or risk attack by more diverse herbivores and pathogens have a greater cognitive capacity.

advances that plant biologists may find useful. We outline a few of these future directions in Box 1.

\section{Acknowledgements}

We thank Maud Ferrari, Michael Sherriff, Jennifer Thaler, Robert Junker, Ian Pearse, and Mikaela Huntzinger for improving this paper.

\section{References and recommended reading}

Papers of particular interest, published within the period of review, have been highlighted as:

- of special interest

•• of outstanding interest

1. Karban R: Plant Sensing and Communication. University of -. Chicago Press; 2015

This book provides a current and accessible review of our understanding of the mechanisms of plant perception of the abiotic and biotic environment and of their responses to those environmental cues.

2. Karban R, Agrawal AA, Thaler JS, Adler LS: Induced plant responses and information content about risk of herbivory. Trends Ecol Evol 1999, 14:443-447.

3. Orrock JL, Sih A, Ferrari MCO, Karban R, Preisser EL, Sheriff MJ,

-. Thaler JS: Error management in plant allocation to herbivore defense. Trends Ecol Evol 2015, 8:441-445.

The authors applied error management theory, developed by engineers and modified by animal behaviorists, to plant defenses against herbivores. This theory predicts when and how plant defenses should be deployed.
4. Schuler MS, Orrock JL: The maladaptive significance of maternal effects for plants in anthropogenically modified environments. Evol Ecol 2012, 26:475-481.

5. Harper JL: The concept of population in modular organisms. In Theoretical Ecology, 2nd ed.. Edited by May RM.. Sinauer Press; 1981:57-77.

6. Stowe KA, Marquis RJ, Hochwender CG, Simms EL: The evolutionary ecology of tolerance to consumer damage. Annu Rev Ecol Syst 2000, 31:565-595.

7. Weissburg M, Smee DL, Ferner MC: The sensory ecology of - nonconsumptive predator effects. Am Nat 2014, 184:141-157. These authors provide a current framework for understanding the cues perceived by animals to detect risk of attack.

8. Bradbury JW, Vehrencamp SL: Principles of Animal Communication. Sinauer Press; 1998.

9. Cipollini DF: Wind-induced mechanical stimulation increases pest resistance in common bean. Oecologia 1997, 111:84-90.

10. Sih A: Prey uncertainty and the balancing of antipredator and feeding needs. Am Nat 1992, 139:1052-1059.

11. Hettyey A, Toth Z, Thonhauser KE, Frommen JG, Penn DJ, Van

-. Buskirk J: The relative importance of prey-borne and predatorborne chemical cues for inducible antipredator responses in tadpoles. Oecologia 2015, 179:699-710.

These authors highlight the differences between pre-consumptive and post-consumptive cues used by animals to detect predators. Their careful experiments highlight the different kinds of information contained by different cues and should stimulate studies by plant biologists.

12. Kim J, Quaghebeur H, Felton GW: Reiterative and interruptive signaling in induced plant resistance to chewing insects. Phytochemistry 2011, 72:1624-1634.

13. Orrock $\mathrm{JL}$, Danielson $\mathrm{BJ}$, Brinkerhoff RJ: Rodent foraging is affected by indirect, but not by direct, cues of predation risk. Behav Ecol 2004, 15:433-437.

14. Verdolin JL: Meta-analysis of foraging and predation risk tradeoffs in terrestrial systems. Behav Ecol Sociobiol 2006, 60:457-464.

15. Duran-Flores D, Heil M: Damaged-self recognition in common bean (Phaseolus vulgaris) shows taxonomic specificity and triggers signaling via reactive oxygen species (ROS). Front Plant Sci 2014, 5:585.

16. Heil M, Land WG: Danger signals - damaged-self recognition -. $\quad$ across the tree of life. Front Plant Sci 2014, 5:578.

The authors present evidence that plants (and animals) recognize molecular patterns associated with damage per se, in addition to the more specific patterns associated with particular attackers. This is a novel hypothesis that should stimulate future work.

17. Bonaventure G: Plants recognize herbivorous insects by complex signalling networks. Annu Plant Rev 2014, 47:1-36

18. Mescher MC, DeMoraes CM: The role of sensory perception in - plant-animal interactions. J Exp Bot 2015, 66:425-433.

These authors review the mechanisms of plant perception. Their review is more complete and inclusive of the diversity of interactions that plants and animals engage in.

19. Yoshinaga N, Aboshi $\mathrm{T}$, Abe H, Nishida R, Alborn HT, Tumlinson JH, Mori N: Active role of fatty acid amino acid conjugates in nitrogen metabolism in Spodoptera litura larvae. Proc Natl Acad Sci U S A 2008, 105:18058-18063.

20. Beyaert I, Koepke D, Stiller J, Hammerbacher A, Yoneya K, Schmidt A, Gershenzon J, Hilker M: Can insect egg deposition "warn" a plant of future feeding damage by herbivorous larvae? Proc $R$ Soc B Biol Sci 2012, 279:101-108.

21. Hilker M, Fatouros NE: Plant responses to insect egg - deposition. Annu Rev Entomol 2015, 60:493-515.

The authors describe how plants perceive and respond to insect eggs. This thorough review ranges from mechanisms to theory.

22. Helms AM, De Moraes CM, Tooker JF, Mescher MC: Exposure of Solidago altissima plants to volatile emissions of an insect antagonist (Eurosta solidaginis) deters subsequent herbivory. Proc Natl Acad Sci U S A 2013, 110:199-204. 
23. Felton GW, Chung SH, Estrada Hernandez MG, Louis J, Peiffer M -. Tian D: Herbivore oral secretions are the first line of protection against plant-induced defences. Annu Plant Rev 2014, 47:37-76.

The authors review the literature on oral secretions as cues that plants recognize. They also propose the novel hypothesis that herbivores avoid detection by providing plants with cues associated with pathogens.

24. Chung SH, Rosa C, Scully ED, Peiffer M, Tooker JF, Hoover K, Luthe DS, Felton GW: Herbivore exploits orally secreted bacteria to suppress plant defenses. Proc Natl Acad Sci U S A 2013, 110:15728-15733.

25. Paudel JR, Bede JC: Ethylene signaling modulates herbivore-

- induced defense responses in the model legume Medicago truncatula. Mol Plant-Microb Interact 2015, 28:569-579.

Caterpillar saliva elicits responses from the JA pathway. The authors used ethylene insensitive mutants to uncover the involvement of ethylene signaling in this process.

26. Orians C: Herbivores, vascular pathways, and systemic induction: facts and artifacts. J Chem Ecol 2005, 31:2231-2242.

27. Karban R, Yang LH, Edwards KF: Volatile communication

- between plants that affects herbivory: a meta-analysis. Ecol Lett 2014, 17:44-52.

This meta-analysis includes more than 50 published and unpublished studies of volatile communication between plant individuals. After decades of controversy, the majority of evidence indicates that this is a rea phenomenon allowing plants to adjust their defenses to perceived risk.

28. Heil M, Karban R: Explaining evolution of plant communication by air-borne signals. Trends Ecol Evol 2010, 25:137-144.

29. Karban R, Shiojiri K: Self-recognition affects plant communication and defense. Ecol Lett 2012, 12:502-506.

30. Karban R, Shiojiri K, Ishizaki S, Wetzel WC, Evans RY: Kin recognition affects plant communication and defence. Proc $R$ Soc B 2013, 280:20123062.

31. Falik O, Mordoch Y, Quansah L, Fait A, Novoplansky A: Rumor has it .... relay communication of stress cues in plants. PLOS ONE 2011, 11:23625

32. Schultz JC, Appel HM, Ferrieri AP, Arnold TM: Flexible resource allocation during plant defense responses. Front Plant Sci 2013, 4:324.

33. Stankowich T, Blumstein DT: Fear in animals: a metaanalysis and review of risk assessment. Proc $R$ Soc $B 2005$, 272:2627-2634

34. Lima SL: Stress and decision making under the risk of predation: recent developments from behavioral, reproductive, and ecological perspectives. Stress Behav 1998 27:215-290.

35. Liscum E, Askinosie SK, Leuchtman DL, Morrow J, Willenburg KT Coats DR: Phototropism: growing towards an understanding of plant movement. Plant Cell 2014, 26:38-55.

36. Waite S: Field evidence for plastic growth responses to habitat heterogeneity in the clonal herb Ranunculus repens. Ecol Res 1994, 9:311-316.

37. Drew MC: Comparison of the effects of a localized supply of phosphate, nitrate, ammonium and potassium on the growth of the seminal root system, and the shoot, of barley. New Phytol 1975, 111:479-490.

38. McNickle GG, Brown JS: When Michaelis and Menton met

- Holling: towards a mechanistic theory of plant nutrient foraging behavior. AoB Plants 2015, 6:plu066.

These authors apply foraging theory developed for animals to understand patterns of root foraging for soil nutrients. The primary contribution of this paper is to develop a model that can be applied to both groups.

39. Ballare CL: Jasmonate-induced defenses: a tale of intelligence, collaborators and rascals. Trends Plant Sci 2011, 16:249-257.

40. Gianoli $\mathrm{E}$ : The behavioural ecology of climbing plants. $A \circ B$ Plants 2015, 7:013.

41. Jensen EL, Dill LM, Cahill JF: Applying behavioral-ecological theory to plant defense: light-dependent movement in Mimosa pudica suggests a trade-off between predation risk and energetic reward. Am Nat 2011, 177:377-381.
42. Louda SM, Rodman JE: Insect herbivory as a major factor in the shade distribution of a native crucifer (Cardamine cordifolia A. Gray, bittercress). J Ecol 1983, 84:229-237.

43. Young TP, Okello BD: Relaxation of an induced defense after exclusion of herbivores: spines on Acacia drepanolobium. Oecologia 1998, 115:508-513.

44. Preisser EL, Orrock JL, Schmitz OJ: Predator hunting mode and habitat domain alter nonconsumptive effects in predator-prey interactions. Ecology 2007, 11:2744-2751.

45. Harvell CD: Complex biotic environments, coloniality, and heritable variation for inducible defenses. In The Ecology and Evolution of Inducible Defenses. Edited by Tollrian R, Harvell CD. Princeton; 1999:231-244.

46. Cipollini D, Walters D, Voelckel C: Costs of resistance in plants: - from theory to evidence. Insect-Plant Interact 2014, 47:263-307. It makes intuitive sense that plant defenses must be costly, but empiricists have had a difficult time documenting these costs. This review examines this theoretical conundrum and reviews the growing evidence for costs of defending against attackers.

47. Clark CW: Antipredator behavior and the asset-protection principle. Behav Ecol 1994, 5:159-170.

48. Boege K, Barton KE, Dirzo R: Influence of tree ontogeny on plant-herbivore interactions. In Size- and Age-Related Changes in Tree Structure and Function. Edited by Meinzer FC, Lachenbruch B, Dawson TE. Springer; 2011:193-214.

49. Barton KE, Koricheva J: The ontogeny of plant defense and herbivory: characterizing general patterns using metaanalysis. Am Nat 2010, 175:481-493.

50. Zangerl AR, Rutledge CE: The probability of attack and patterns of constitutive and induced defense: a test of optimal defense theory. Am Nat 1996, 147:599-608.

51. Dukas R: Evolutionary biology of animal cognition. Annu Rev Ecol Evol Syst 2004, 35:347-374

52. Cole EF, Morand-Ferron J, Hinks AE, Quinn JL: Cognitive ability influences reproductive life history variation in the wild. Curr Biol 2012, 22:1808-1812.

53. Kimchi T, Terkel J: Seeing and not seeing. Curr Opin Neurobiol $2002,12: 728-734$

54. Semchenko M, Zobel K, Heinemeyer A, Hutchings MJ: Foraging for space and avoidance of physical obstructions by plant roots: a comparative study of grasses from contrasting habitats. New Phytol 2008, 179:1162-1170.

55. Gagliano $\mathrm{M}$ : In a green frame of mind: perspectives on the - behavioural ecology and cognitive nature of plants. AoB Plants 2015, 7:075

In this provocative review, the author pushes the field by arguing that plants exhibit cognitive abilities.

56. Engleberth J, Alborn HT, Schmelz EA, Tumlinson JH: Airborne signals prime plants against herbivore attack. Proc Natl Acad Sci U S A 2004, 101:1781-1785.

57. Conrath U: Molecular aspects of defence priming. Trends Plant Sci 2011, 16:524-531.

58. Herms DA, Mattson WJ: The dilemma of plants - to grow or defend. Q Rev Biol 1992, 67:283-335.

59. Thaler J, Humphrey PT, Whiteman NK: Evolution of jasmonate and salicylate signal crosstalk. Trends Plant Sci 2012, 17:260-270.

60. Yamazaki K: Gone with the wind: trembling leaves may deter herbivory. Biol J Linn Soc 2011, 104:738-747.

61. Warren J: Is wind-mediated passive leaf movement an effective form of herbivore defence? Plant Ecol Evol 2015 , 148:52-56.

Plants are not capable of moving at the same spatial scale as animals. However, experiments and observations suggest that leaf mobility may provide a defense against herbivores and these provocative results should stimulate further work. 
62. Gorzelak MA, Asay AK, Pickles BJ, Simard SW: Inter-plant

- communication through mycorrhizal networks mediates complex adaptive behavior in plant communities. AoB Plants 2015, 7:050.

Recently, it has become clear that mycorrhizal networks are both common in many systems and are an important means of information transfer. The authors provide a nuanced review of the limitations and intricacies of this phenomenon.

63. Song YY, Zeng RS, Xu JF, Li J, Shen X, Yindego WG: Interplant communication of tomato plants through underground common mycorrhizal networks. PLOS ONE 2010, 5:e13324.

64. Babikova Z, Gilbert L, Bruce TJA, Birkett M, Caulfield JC,

•- Woodcock C, Pickett JA, Johnson D: Underground signals carried through common mycelial networks warn neighbouring plants of aphid attack. Ecol Lett 2013, 16:835-843.

Mycorrhizal networks had been found to connect individual plants and transfer nutrients. This important study extends those findings by showing that mycorrhizae also transfer cues of herbivory, allowing neighbors to defend before being attacked themselves.

65. Isbell LA: The Fruit, the Tree, and the Serpent: Why We See So Well. Harvard University Press; 2009.

66. Ballare CL: Illuminated behaviour: phytochrome as a key regulator of light foraging and plant anti-herbivore defence. Plant Cell Environ 2009, 32:713-725.

67. Borst A: Drosophila's view on insect vision. Curr Biol 2009, 19:36-47.

68. Galen C, Huddle J, Liscum E: An experimental test of the adaptive evolution of phototropins: blue-light photoreceptors controlling phototropism in Arabidopsis thaliana. Evolution 2004, 58:515-523.
69. Broz $\mathrm{P}$, Monack DM: Newly described pattern recognition receptors team up against intracellular pathogens. Nat Rev Immunol 2013, 13:551-565.

70. Acevedo FE, Rivera-Vega LJ, Chung SH, Ray S, Felton GW: Cues from chewing insects - the intersection of DAMPs, HAMPs, MAMPs and effectors. Curr Opin Plant Biol 2015, 26:80-86.

71. ter Hofstede HM, Goerlitz HR, Ratcliffe JM, Holderled MW, Surlykke A: The simple ears of noctuoid moths are tuned to the calls of their sympatric bat community. J Exp Biol 2013, 216:3954-3962.

72. Appel HM, Cocroft RB: Plants respond to leaf vibrations caused by insect herbivore chewing. Oecologia 2014, 175:1257-1266. Vibrations caused by caterpillar feeding caused Arabidopsis to prime defenses against subsequent attack. This is the first convincing demonstration of insect vibrations as a cue that plants perceive.

73. Casas J, Dangles O: Physical ecology of flow sensing in arthropods. Annu Rev Entomol 2010, 55:505-520.

74. Peiffer M, Tooker JF, Luthe DS, Felton GW: Plants on early alert: glandular trichomes as sensors for insect herbivores. New Phytol 2009, 184:644-656.

75. Bradshaw AD: Evolutionary significance of phenotypic plasticity in plants. Adv Genet 1965, 13:115-155.

76. Borges RM: Do plants and animals differ in phenotypic plasticity? J Biosci 2005, 30:41-50.

77. Sih A, Cote J, Evans M, Fogarty S, Pruitt J: Ecological implications of behavioural syndromes. Ecol Lett 2012 , 15:278-289. 